\title{
Review on Energy and Exergy Analysis of Air and Water Based Photovoltaic Thermal (PVT) Collector
}

\author{
Muslizainun Mustapha, Ahmad Fudholi, Chan Hoy Yen, Mohd Hafidz Ruslan, \\ Kamaruzzaman Sopian \\ Solar Energy Research Institute, Universiti Kebangsaan Malaysia, Malaysia
}

\begin{tabular}{l}
\hline \hline Article Info \\
\hline Article history: \\
Received Feb 7, 2018 \\
Revised Aug 3, 2018 \\
Accepted Aug 6, 2018
\end{tabular}

\section{Keyword:}

Electricity

Energy

Exergy

Photovoltaic thermal

Thermal energy

\begin{abstract}
Hybrid photovoltaic-thermal (PVT) collector has been developed by combining photovoltaic (PV) technology and solar thermal collector in one module. The combination of two technologies in the same module has the potential to reduce cost of materials and the required space also improves performance of collectors. The hybrid PVT collectors were designed to generate electrical and thermal energy simultaneously. PV technology converts solar radiation into electrical energy while solar thermal collector will be converting solar energy to thermal energy. The main components of PVT collectors are PV panel, absorber plate, working fluid and insulator. According to the previous research, PVT collectors were developed by using air and water as a heat transfer medium. The benefits of heat removal are increasing PV panel efficiency by removing excessive heat from module. Parameters affecting the overall performances of PVT collectors included mass flow rate, area of collector, irradiance and PV cell materials. This paper presents a review of energy and exergy analysis of air-based and water-based PVT collector with different designs. The performances of PVT collectors were studied using First Law and Second Law of Thermodynamics. This study has found that generally the energy and exergy efficiency are range from $40 \%-70 \%$ and $5 \%-25 \%$, respectively.
\end{abstract}

Copyright $(9) 2018$ Institute of Advanced Engineering and Science. All rights reserved.

\section{Corresponding Author:}

Muslizainun Mustapha,

Solar Energy Research Institute, Universiti Kebangsaan Malaysia,

43600 Bangi Selangor, Malaysia.

Email: muslizainun@gmail.com

\section{INTRODUCTION}

The growth of population and economic development in most of the countries in this world has increased the global energy needs. The International Energy Agencies (IEA) pointed out that increasing energy consumption for developing countries is faster than developed countries, and they required almost double of their current capacity to fulfill the energy demand by the year 2020. It is also estimated that the total world energy consumption will be increasing by $44 \%$ from 2006 to 2030 [1]-[3]. Therefore, an alternative energy source must determine to meet our energy requirements and for the preservation of conventional fossil fuels. Solar energy is one of the renewable energy sources and this clean energy has potential to meet a significant amount of the world's energy demand [4]-[7] . Basically, solar systems can be categorised into two types which are thermal systems and photovoltaic technology [8]-[10]. Thermal collector will convert solar energy to thermal energy whereas photovoltaic technology converts solar radiation into electricity. Generally, thermal collector and photovoltaic collector are used separately. However, according to the previous research, the combination of both technologies in one system has the potential to reduce the required space, the use of materials and the cost of installation.

This system has known as hybrid photovoltaic thermal (PV/T) technology [11-13]. Photovoltaic thermal (PVT) collector is a combination of photovoltaic (PV) module and thermal collector in a single unit 
to generate electricity and thermal energy simultaneously. The main components of PVT collector are PV panel, absorber, working fluid and insulator. Research on PVT collector has been conducted over the last 25 years with the main objective of the research is to determine the most effective system of PVT to generate higher energy efficiency [14]. The hybrid PVT collector generated more energy per unit surface area than PV panel and thermal collector are used separately [15]. The energy conversion efficiency of solar radiation into electricity by PV panel ranges between $12 \%$ to $18 \%$, and up to $80 \%$ of irradiance either reflected or turn into heat as stated by Agrawal in 2010 [16]. In the paper by Chow [17], he indicated that increasing the temperature of the PV panel reduces the efficiency which is every increase of $10^{\circ} \mathrm{C}$ caused a decrease in panel efficiency of 5\%. However, few researchers [18]-[20] have suggested that the efficiency of the PV panel can be increase by removing excessive heat from PV panel using cooling fluids such as air and water.

The objective of this paper is to review the performances of PVT collectors with different types of working fluids such as air and water. In addition, the overall performances of the PVT collector can be evaluated both experimentally and numerically based on energy and exergy analysis of the systems. The reported data and results are tabulated to show an overall efficiency of the systems regarding to the thermal energy and electricity production, and also energy and exergy efficiency.

\section{TYPES OF PVT COLLECTORS}

As shown in Figure 1, PV/T collector can be categorized into air-based PV/T collector, water-based PVT collector, and combination of air and water as heat transfer fluids. PVT water collectors are more efficient than PVT air collectors due to high heat conductivity of water as compared to air. However, airbased PVT are cheaper and most popular because of the flexibility of PV collector that can be simply changed to a PVT collector with a few adjustments [21]. The main components of PVT collectors consist of a PV panel on the top which converts solar radiation into electrical energy [22], absorber plate, and insulator materials at the bottom of the collector as shown in Figure 2. The purpose of thermal absorber underneath the module is to capture the remaining energy and removes excessive heat from the module. While this process occurs, the temperature of PV panel decreases and thus improving its electrical efficiency. Therefore, the generation of both electricity and thermal energy allows these hybrid systems to have higher exergy [23] and produce greater energy efficiency compared to solar thermal and solar PV alone [24]. As reported by Adnan et al. [14], the best absorber collector design was the spiral, with energy efficiency of $64 \%$ compared to other design of absorber collectors such as direct flow, serpentine flow and oscillatory flow.

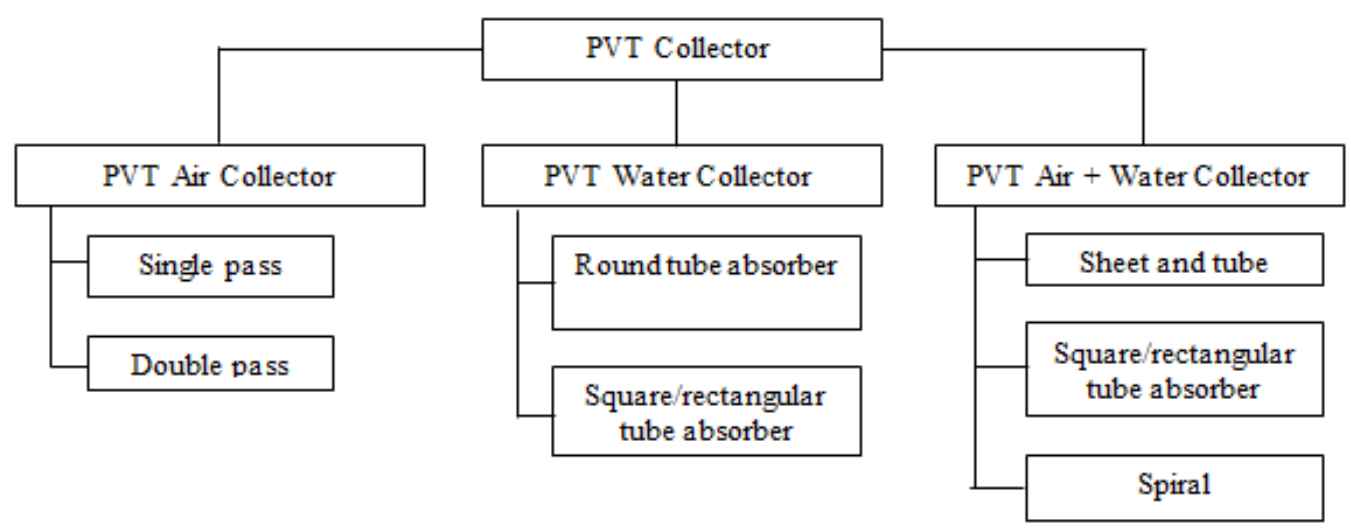

Figure 1. Classifications of PVT collectors [14]

Besides that, one of the important operating parameter in running the PVT collector is mass flow rate. The mass flow rate should be sufficient enough to absorb the heat in order to increase PV efficiency and thermal energy production. Fudholi et al. [25] did research on energy and exergy analysis of water based PVT collector with spiral flow absorber. The study showed that the energy efficiency varied from $58 \%$ to $68 \%$ and the PVT exergy efficiency ranged from $40 \%$ to $50 \%$ at the mass flow rate $0.011 \mathrm{~kg} / \mathrm{s}$ to $0.041 \mathrm{~kg} / \mathrm{s}$ and solar radiation of $800 \mathrm{~W} / \mathrm{m}^{2}$. In another research, Chandra et al. [26] developed an air type single-pass PVT collector with rectangular fins. They found that the maximum PV efficiency and thermal efficiency were obtained about $13.75 \%$ and $56.19 \%$ respectively for four fins at $0.14 \mathrm{~kg} / \mathrm{s}$ of mass flow rate. Apart from 
typical PVT collector design, Othman et al. [27] conducted the performances analysis of PVT combi with water and air heating. The major components fabricated in the system are double-pass flat plat air collector and copper water tube. While the air flow rate and water flow rate was $0.05 \mathrm{~kg} / \mathrm{s}$ and $0.02 \mathrm{~kg} / \mathrm{s}$, respectively, they determined the average electrical power generation achieved was $145 \mathrm{~W}$ with electrical efficiency of $17 \%$ and thermal efficiency accomplished was $76 \%$. Yet another research of PVT collector was presented by Tripathi et al. [28]. The study has highlighted the energy-exergy for partialaly covered concentrated PVT collector with water and dimethyl-diphenyl silicone fluid (DMDP) as a working fluid. The annual net gain for electrical, overall energy and exergy has been found as $12.35 \mathrm{kWh}, 304.46 \mathrm{kWh}$ and $50.58 \mathrm{kWh}$ respectively.

a)

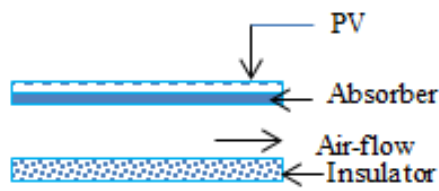

b)

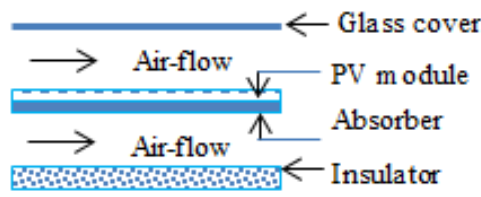

c)

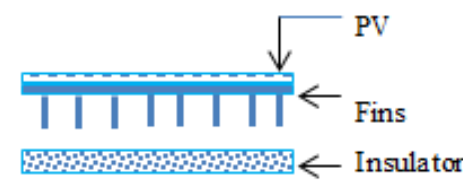

d)

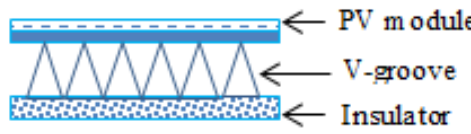

e)

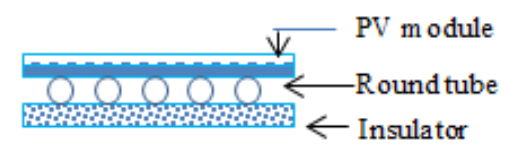

Figure 2. Cross-section of different types of PVT collectors. (a) Single pass air-based PVT collector, (b) Double pass air-based PVT collector, (c) PVT collector with fins, (d) PVT collector with v-groove absorber, (e) PVT collector with round tube absorber

In addition, the material of the PV solar cell affects the electric yield of PVT collector. PV solar cell materials can be catogarized into silicon solar cells, thin film solar cells and dye sensitized solar cells. According to Saini et al. [29], they discussed the electrical and thermal performance of N PVT-CPC collector with different types of solar cells. It was seen that the maximum net annual electrical anergy obtained for $\mathrm{N}$ PVT-CPC collector with monocrystalline solar cells is around 2 times higher than N PVT-CPC collector with amorphous thin film solar cells.

\section{PERFORMANCE OF PVT COLLECTOR}

\subsection{Energy Analysis}

The performance of PVT collectors can be represented by the sum of efficiency expression [30]. It is included of electrical efficiency $\left(\eta_{P V}\right)$ and thermal efficiency $\left(\eta_{t h}\right)$, which are defined as the ratios of useful electrical gain and heat gain to incident solar radiation striking on the panel's collecting surface[25], [31], [32]. According to Huang et al. [33], the total energy efficiency of PVT $\left(\eta_{P V T}\right)$ systems can be determined by:

$$
\eta_{P V T}=\eta_{P V}+\eta_{t h}
$$

The electrical efficiency and thermal efficiency of a PVT collectors are, respectively given by [34]:

$$
\begin{aligned}
\eta_{P V} & =\frac{I_{m} V_{m}}{S A_{c}} \\
\eta_{\text {th }} & =\frac{m C\left(T_{\text {out }}-T_{\text {in }}\right)}{S A_{c}}
\end{aligned}
$$

where $I_{m}$ and $V_{m}$ are the electric current and voltage at maximum power point operation, $S$ the incident solar 
irradiation, $A_{c}$ the area of the collector, $m$ the mass flow rate of working fluid, $C$ the specific heat capacity of the coolant, $T_{\text {in }}$ and $T_{\text {out }}$ the coolant (air or water) temperatures at the inlet and outlet. Basically, electrical efficiency also can be calculated in terms of module temperature is given as follows:

$$
\eta_{P V}=\eta_{r e f}\left[1-\beta_{r e f}\left(T_{p v}-T_{r e f}\right)\right]
$$

where $\eta_{r e f}$ is reference efficiency of PV module, $\beta_{r e f}$ is temperature coefficient, $T_{p v}$ is module temperature and $T_{r e f}$ is reference temperature.

\subsection{Exergy Analysis}

According to the previous research, PVT collector will produced the amount of energy in form of electrical and thermal energy. The maximum quantity of work that can be produced in some given environment named exergy. In addition, the work will has produced by thermal energy until a temperature difference exists between heat source and heat sink [35]. However, electrical energy can completely convert into work irrespective of the environment. Therefore, the exergy analysis can be created based on the second law of thermodynamics in terms of total exergy inflow $\left(E x_{i n}\right)$, exergy outflow $\left(E x_{\text {out }}\right)$ and exergy destructed $\left(E x_{\text {dest }}\right)$ from the system. In PVT system, exergy balance can be expressed as:

$$
E x_{\text {in }}-E x_{\text {out }}=E x_{\text {dest }}
$$

Where

$$
\begin{aligned}
& E x_{\text {in }}=A N S\left[1-\left(\frac{4}{3}\left(\frac{T_{a}}{T_{s}}\right)+\frac{1}{3}\left(\frac{T_{a}}{T_{s}}\right)^{4}\right)\right] \\
& E x_{o u t}=E x_{P V}+E x_{t h}
\end{aligned}
$$

where $A$ is the area of the collector, $N$ is collectors number, $S$ is the incident solar radiation, $T_{a}$ is the ambient temperature and $T_{S}$ is the sun temperature in Kelvin. The electrical exergy $\left(E x_{P V}\right)$ and thermal exergy $\left(E x_{t h}\right)$ can be written as follows:

$$
\begin{aligned}
& E x_{P V}=\eta_{P V} A S \\
& E x_{\text {th }}=m C\left(T_{\text {out }}-T_{\text {in }}\right)\left[1-\frac{T_{a}+273}{T_{\text {out }}+273}\right]
\end{aligned}
$$

Therefore,

$$
E x_{P V T}=E x_{P V}+E x_{t h}
$$

where, $E x_{P V T}$ is photovoltaic thermal exergy, $A$ is the $\mathrm{PV}$ area, and $S$ is the incident solar radiation. So as a result of exergy analysis, the exergy efficiency $\left(\eta_{E x_{P V T}}\right)$ is the ratio of total exergy output to the total exergy input, then

$$
\eta_{E x_{P V T}}=\frac{E x_{o u t}}{E x_{i n}}
$$

\begin{tabular}{|c|c|c|c|c|c|}
\hline \multirow{2}{*}{ Authors Ref. } & \multirow{2}{*}{ Type of PVT Collectors } & \multicolumn{3}{|c|}{ Energy Efficiency (\%) } & \multirow{2}{*}{$\begin{array}{l}\text { Exergy Efficiency } \\
(\%)\end{array}$} \\
\hline & & PV & Thermal & Overall & \\
\hline
\end{tabular}

Table 1 provides the result of energy and exergy analysis of PVT collectors as reported from different previous studies. It is found that most of the collectors could achieve a maximum energy efficiency and exergy efficiency of about $40 \%-75 \%$ and $5 \%-25 \%$, respectively, for air and water cooled PVT collector. The overall performances of PVT collector efficiency depend on some parameters such as the type of working fluid, mass flow rate, PV cell materials, types of the absorber plate and area of the collector.

Table 1. Summary of Different PVT Collectors 


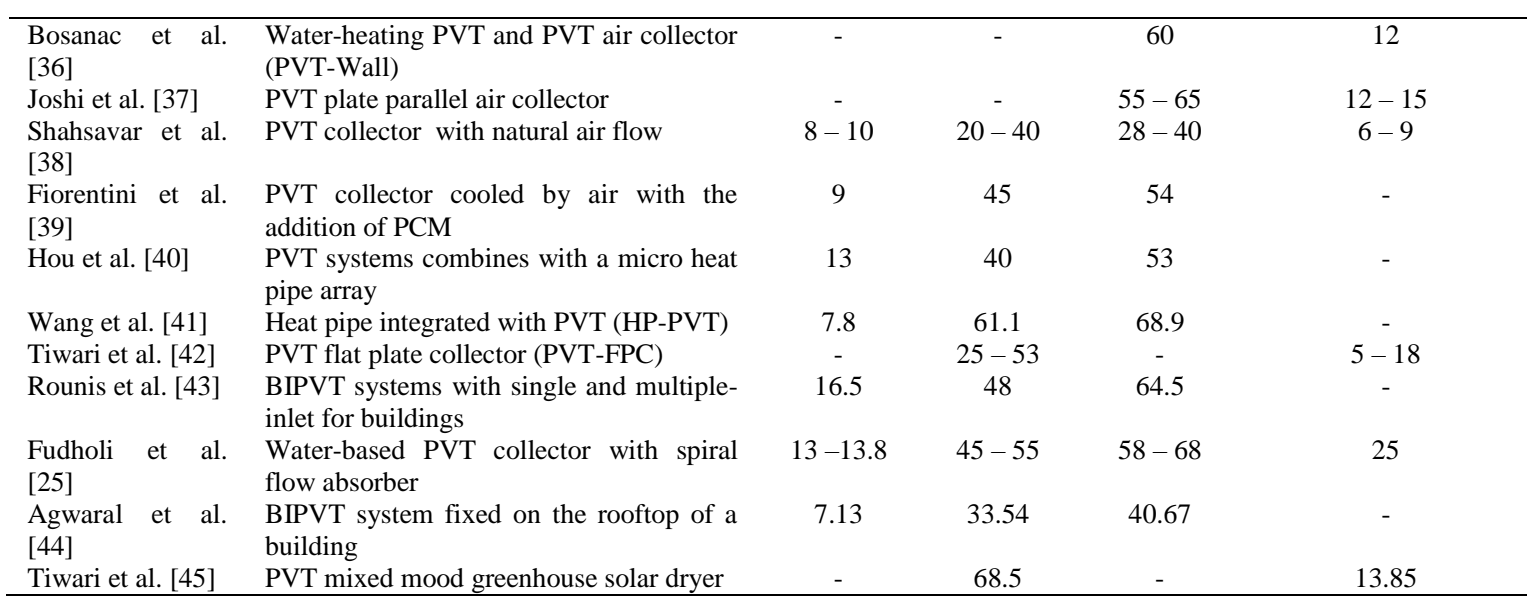

\section{CONCLUSIONS}

This paper reviewed the development in various design of PVT collectors that focused on the analysis of energy and exergy efficiencies. The electrical and thermal efficiency are also one of the most important parameter to be considered in PVT system. The review shows that, electrical efficiency is range from $10 \%$ to $25 \%$ and thermal efficiency are from $40 \%$ to $75 \%$. The significant findings from this review are the energy and exergy efficiency of the PVT collectors are between $40 \%-70 \%$ and 5\%-20\%, respectively. According to the previous researches, the performances of the PVT collectors can be improved by modifiying the collector design. For the case of air-based PVT collectors, fins were attached at the flat-plat absorber in order to get larger heat transfer area. Therefore, higher the temperature drop experienced at the PV panel surface and thus panel efficiency will increase. In addition to the above modifications, water-based PVT collecter can be integrated with sheet-and-tube channel to increase heat transport.

\section{ACKNOWLEDGEMENTS}

The authors would like to thank Solar Energy Research Institute (SERI), from National University of Malaysia for funding (GP-K020448) and (DLP-2015-005).

\section{REFERENCES}

[1] A. H. A. Al-waeli, K. Sopian, H. A. Kazem, M. T. Chaichan, "Photovoltaic/Thermal (PV/T) systems: Status and future prospects," Renew. Sustain. Energy Rev., vol. 77, no. March, pp. 109-130, 2017.

[2] R. Daghigh, A. Ibrahim, G. Li, M. Hafidz, K. Sopian, "Predicting the performance of amorphous and crystalline silicon based photovoltaic solar thermal collectors," Energy Convers. Manag., vol. 52, no. 3, pp. 1741-1747, 2011.

[3] J. Yoon, J. Song, S. Lee, "Practical application of building integrated photovoltaic (BIPV) system using transparent amorphous silicon thin-film PV module," Sol. Energy, vol. 85, no. 5, pp. 723-733, 2011.

[4] A. Fudholi, K. Sopian, "R \& D of Photovoltaic Thermal ( PVT ) Systems : an Overview," International Journal of Power Electronics and Drive System (IJPEDS), vol. 9, no. 2, pp. 803-810, 2018.

[5] N. S. Nazri, A. Fudholi, M. H. Ruslan, K. Sopian, "Mathematical Modeling of Photovoltaic ThermalThermolelectric (PVT-TE) air collector," International Journal of Power Electronics and Drive System (IJPEDS), vol. 9, no. 2, pp. 795-802, 2018.

[6] R. Palanisamy, K. Vijayakumar, "Wind-PV Hybrid Energy Source Fed Three Level NPC with Quasi Z Source Network," International Journal of Power Electronics and Drive System (IJPEDS), vol. 8, no. 3, pp. 1285-1293, 2017.

[7] M. Zohri, L. D. Bakti, A. Fudholi, "Exergy Assessment of Photovoltaic Thermal with V-groove Collector Using Theoretical study," Telkomnika, vol. 16, no. 2, pp. 550-557, 2018.

[8] M. Zohri, A. Fudholi, "Photovoltaic-Thermal ( PVT ) System with and Without Fins Collector: Theoretical Approach," International Journal of Power Electronics and Drive System (IJPEDS), vol. 8, no. 4, pp. 1756-1763, 2017.

[9] A. Fudholi, K. Sopian, "Review on Solar Collector for Agricultural Produce," International Journal of Power Electronics and Drive System (IJPEDS), vol. 9, no. 1, pp. 414-419, 2018.

[10] A. Fudholi, K. Sopian, "Review on Exergy and Energy Analysis of Solar Air Heater," International Journal of Power Electronics and Drive System (IJPEDS), vol. 9, no. 1, pp. 420-426, 2018.

[11] D. Atheaya, A. Tiwari, G. N. Tiwari, "Exergy analysis of photovoltaic thermal ( PVT ) compound parabolic concentrator ( CPC ) for constant collection temperature mode," Sol. Energy, vol. 135, pp. 222-231, 2016.

[12] A. Shahsavar, M. Salmanzadeh, M. Ameri, P. Talebizadeh, "Energy saving in buildings by using the exhaust and ventilation air for cooling of photovoltaic panels," Energy Build., vol. 43, no. 9, pp. 2219-2226, 2011. 
[13] A. Fudholi, K. Sopian, B. Bakhtyar, M. Gabbasa, M. Yusof, M. Ha, "Review of solar drying systems with air based solar collectors in Malaysia," Renew. Sustain. Energy Rev, vol. 51, pp. 1191-1204, 2015.

[14] A. Ibrahim, M. Y. Othman, M. H. Ruslan, S. Mat, K. Sopian, "Recent advances in flat plate photovoltaic / thermal ( PV / T ) solar collectors," Renew. Sustain. Energy Rev., vol. 15, no. 1, pp. 352-365, 2011.

[15] H. A. Zondag, D. W. D. E. Vries, W. G. J. V. A. N. Helden, R. J. C. V. A. N. Zolingen, A. A. V. A. N. Steenhoven, "The thermal and electrical yield of a pv-thermal collector," Solar Energy, vol. 72, no. 2, pp. 113-128, 2002.

[16] B. Agrawal, d G. N. Tiwari, "Optimizing the energy and exergy of building integrated photovoltaic thermal (BIPVT) systems under cold climatic conditions,” Appl. Energy, vol. 87, no. 2, pp. 417-426, 2010.

[17] T. T. Chow, J. W. Hand, P. A. Strachan, "Building-integrated photovoltaic and thermal applications in a subtropical hotel building," Applied Thermal Engineering, vol. 23, no. 16. pp. 2035-2049, 2003.

[18] M. N. Abu Bakar, M. Othman, M. Hj Din, N. A. Manaf, H. Jarimi, "Design concept and mathematical model of a bi-fluid photovoltaic/thermal (PV/T) solar collector," Renew. Energy, vol. 67, pp. 153-164, 2014.

[19] S. Dubey, G. N. Tiwari, "Thermal modeling of a combined system of photovoltaic thermal ( PV / T ) solar water heater," Solar Energy, vol. 82, pp. 602-612, 2008.

[20] A. A. Hegazy, "Comparative study of the performances of four photovoltaic/thermal solar air collectors," Energy Convers. Manag., vol. 41, no. 8, pp. 861-881, 2000.

[21] M. A. Hasan, K. Sumathy, "Photovoltaic thermal module concepts and their performance analysis : A review," Renew. Sustain. Energy Rev., vol. 14, no. 7, pp. 1845-1859, 2010.

[22] U. M. Jakarta, A. Info, "The Improvement of Solar Cell Output Power Using Cooling and Reflection from Mirror," International Journal of Power Electronics and Drive System (IJPEDS), vol. 8, no. 3, pp. 1320-1326, 2017.

[23] M. J. M. Pathak, P. G. Sanders, J. M. Pearce, "Optimizing limited solar roof access by exergy analysis of solar thermal, photovoltaic, and hybrid photovoltaic thermal systems," Appl. Energy, vol. 120, pp. 115-124, 2014.

[24] C. Good, "Environmental impact assessments of hybrid photovoltaic - thermal (PV/T) systems - A review," Renew. Sustain. Energy Rev., vol. 55, pp. 234-239, 2016.

[25] A. Fudholi, A. Ibrahim, M. Othman, "Energy and Exergy Analyses on Water based Photovoltaic Thermal (PVT) Collector with Spiral Flow Absorber," Int. Conf. Adv. Energy, Environ. Geol., pp. 70-74, 2014.

[26] J. Chandra, W. Tong, H. Chyuan, K. Y. Leong, "An experimental investigation on performance analysis of air type photovoltaic thermal collector system integrated with cooling fins design," Energy Build., vol. 130, pp. 272-285, 2016.

[27] M. Y. Othman, S. A. Hamid, M. A. S. Tabook, K. Sopian, M. H. Roslan, Z. Ibarahim, "Performance analysis of PV / T Combi with water and air heating system : An experimental study," Renew. Energy, vol. 86, pp. 716-722, 2016.

[28] V. K. D. R. Tripathi, G. N. Tiwari, T. S. Bhatti, "2-E (Energy-Exergy) for partially covered concentrated photovoltaic thermal (PVT) collector," Energy Procedia, vol. 142, pp. 616-623, 2017.

[29] V. Saini, R. Tripathi, G. N. Tiwari, I. M. Al-helal, "Electrical and thermal energy assessment of series connected N partially covered photovoltaic thermal ( PVT ) -compound parabolic concentrator ( CPC ) collector for different solar cell materials," Appl. Therm. Eng., vol. 128, pp. 1611-1623, 2018.

[30] X. Zhang, X. Zhao, S. Smith, J. Xu, X. Yu, "Review of R \& D progress and practical application of the solar photovoltaic/thermal (PV/T) technologies,” Renew. Sustain. Energy Rev., vol. 16, no. 1, pp. 599-617, 2012.

[31] W. He, Y. Zhang, J. Ji, "Comparative experiment study on photovoltaic and thermal solar system under natural circulation of water," Appl. Therm. Eng., vol. 31, no. 16, pp. 3369-3376, 2011.

[32] E. Radziemska, "Performance Analysis of a Photovoltaic-Thermal Integrated System," International Journal of Photoenergy, pp. 6, 2009.

[33] B. J. Huang, T. H. Lin, W. C. Hung, F. S. Sun, "Performance evaluation of solar photovoltaic/thermal systems," Sol. Energy, vol. 70, no. 5, pp. 443-448, 2001.

[34] T. T. Chow, "A review on photovoltaic/thermal hybrid solar technology," Appl. Energy, vol. 87, no. 2, pp. 365$379,2010$.

[35] T. T. Chow, G. Pei, K. F. Fong, Z. Lin, A. L. S. Chan, J. Ji, "Energy and exergy analysis of photovoltaic - thermal collector with and without glass cover," Appl. Energy, vol. 86, no. 3, pp. 310-316, 2009.

[36] M. Bosanac, B. Sørensen, I. Katic, H. Sørensen, B. Nielsen, J. Badran, "Final Report EFP project 1713 / 00-0014 Photovoltaic / Thermal Solar Collectors and Their Potential in Denmark", pp. 114, 2003.

[37] A. S. Joshi, A. Tiwari, "Energy and exergy efficiencies of a hybrid photovoltaic - thermal (PV/T) air collector," Renew. Energy, vol. 32, pp. 2223-2241, 2007.

[38] A. Shahsavar, M. Ameri, M. Gholampour, "Energy and Exergy Analysis of a Photovoltaic-Thermal Collector With Natural Air Flow," J. Sol. Energy Eng., vol. 134, no. 1, p. 11014, 2012.

[39] M. Fiorentini, P. Cooper, Z. Ma, "Development and optimization of an innovative HVAC system with integrated PVT and PCM thermal storage for a net-zero energy retrofitted house," Energy Build., vol. 94, pp. 21-32, 2015.

[40] L. Hou, Z. Quan, Y. Zhao, L. Wang, G. Wang, "An experimental and simulative study on a novel photovoltaicthermal collector with micro heat pipe array (MHPA-PV/T),” Energy Build., vol. 124, pp. 60-69, 2016.

[41] Z. Wang, J. Zhang, Z. Wang, W. Yang, X. Zhao, "Experimental investigation of the performance of the novel HPBIPV/T system for use in residential buildings," Energy Build., vol. 130, pp. 295-308, 2016.

[42] G. N. Tiwari, R. K. Mishra, S. C. Solanki, "Photovoltaic modules and their applications: A review on thermal modelling," Appl. Energy, vol. 88, no. 7, pp. 2287-2304, 2011.

[43] E. D. Rounis, A. K. Athienitis, T. Stathopoulos, "Multiple-inlet Building Integrated Photovoltaic/Thermal system modelling under varying wind and temperature conditions," Sol. Energy, vol. 139, pp. 157-170, 2016.

[44] B. Agrawal, G. N. Tiwari, "Life cycle cost assessment of building integrated photovoltaic thermal (BIPVT) 
systems," Energy and Buildings, vol. 42, no. 9. pp. 1472-1481, 2010.

[45] S. Tiwari, G. N. Tiwari, "Exergoeconomic analysis of photovoltaic-thermal ( PVT ) mixed mode greenhouse solar dryer," Energy, vol. 114, pp. 155-164, 2016.

\section{BIOGRAPHIES OF AUTHORS}

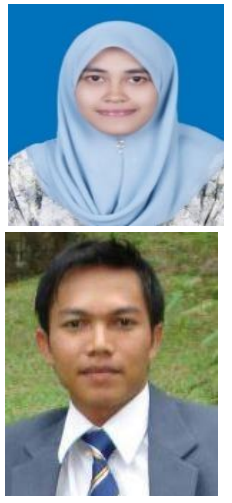

Muslizainun Mustapha Graduated with Bachelor of Science (Hons) in Physics from University Putra Malaysia in 2011 and Master in Science (Renewable Energy) from University Kebangsaan Malaysia in 2012. She has teaching experience about 5 years as a Physics' lecturer at higher educational level. Currently, she is a PhD candidate at the Solar Energy Research Institute (SERI) in University Kebangsaan Malaysia and her research focus on Renewable Energy especially in Photovoltaic Thermal Technologies.

Ahmad Fudholi, Ph.D, M.Sc obtained his S.Si (2002) in physics. He was born in 1980 in Pekanbaru, Indonesia. He served as was the Head of the Physics Department at Rab University Pekanbaru, Riau, Indonesia, for four years (2004-2008). A. Fudholi started his master course in Energy Technology (2005-2007) at Universiti Kebangsaan Malaysia (UKM). After obtaining his Master's, he became a research assistant at UKM until. After his Ph.D (2012) in renewable energy, he became postdoctoral in the Solar Energy Research Institute (SERI) UKM until 2013. He joined the SERI as a lecturer in 2014. He received more than USD 350,000 worth of research grant (16 grant/project) in 2014-2018. He supervised and completed more than 27 M.Sc projects. To date, he has managed to supervise five $\mathrm{Ph} . \mathrm{D}$ (four as main supervisors and one as co-supervisor), three Master's student by research mode and five Master's student by coursework mode. He was also an examiner (three Ph.D and one M.Sc). His current research focus is renewable energy, particularly solar energy technology, micropower systems, solar drying systems and advanced solar thermal systems (solar-assisted drying, solar heat pumps, PVT systems). He has published more than 120 peer-reviewed papers, of which 25 papers are in the ISI index ( $20 \mathrm{Q} 1$, impact factor more than 4) and more than 70 papers are in the Scopus index. He has 16 currently accepted manuscripts, 20 manuscripts currently under review and two book chapters. In addition, he has published more than 70 papers in international conferences. He has a total citations of 830 and a h-index of 14 in Scopus (Author ID: 57195432490). He has a total citations of 1416 and a h-index of 20 in Google Scholar.

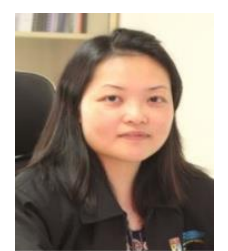

Chan Hoy Yen did her bachelor degree in Chemical Technology (2001-2004) and master degree in Energy Technology (2006-2007) at Universiti Kebangsaan Malaysia (UKM), and her PhD in solar energy (2008-2011) at University of Nottingham in United Kingdom. Currently, she is a research fellow at the Solar Energy Research Institute (SERI), UKM. Her main research area is building integrated solar thermal technology. In addition, she has also contributed to some national and international programmes. She was one of the panellists in the Panel Discussion session on Renewable Energy Curriculum Development during the 6th University Network of Climate and Ecosystems Change Adaptation Research (UN-CECAR) International Conference. She was then appointed by the UN-CECAR as the Malaysian Focal Point to develop the renewable energy courses for the United Nations University.

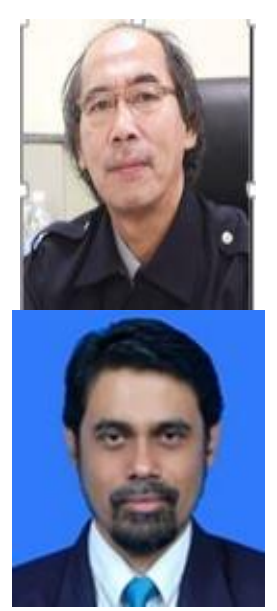

Prof. Dr. Mohd Hafidz Ruslan currently is the Deputy Director and Head of Postgrade Studies of the Solar Energy Research Institute (SERI) UKM, Malaysia. His current research focuses on solar energy, especially solar thermal technology, heat pump system, solar water heating and solar drying systems. He has published more than 150 peer-reviewed papers in ISI and Scopus index. Addition, he has published more than 100 papers in international conferences. His total citations of 1541 by 1077 documents and h-index of 22 in Scopus index (Author ID: 6504666472). His total citations of 2564 and h-index of 27 in google scholar index.

Prof Dato' Dr. Kamaruzzaman Sopian graduated with the BS Mechanical Engineering from the University of Wisconsin-Madison in 1985, the MS in Energy Resources University of Pittsburgh in 1989 and PhD in Mechanical Engineering from the Dorgan Solar Laboratory, University of Miami at Coral Gables in 1997. He has been involved in the field of renewable energy for more than 25-years. He has secure research funding from the Malaysian Minstry of Science and Malaysian Ministry of Education and industry for more than USD 6 million. He has conducted renewable enery courses the Asian School of Energy (2007-2014) funded by ISESCO, COMSAT, TIKA and UNESCO. He has published over 800 research papers in journals and conferences (SCOPUS h index $=49$, no. of citation $=8181)($ Google Scholar $\mathrm{h}$ index $=60$, no. of citation =13761). A total of $32 \mathrm{MSc}$ (coursework), $15 \mathrm{MSc}$ (research mode) and $40 \mathrm{PhD}$ supervised and completed. 